\title{
ANALISIS KEPUASAN MAHASISWA MENGGUNAKAN SIAKAD DALAM PROSES PEMBELAJARAN (STUDI PADA MAHASISWA STIE LABUHAN BATU)
}

\author{
Elida Florentina Sinaga Simanjorang
}

Sekolah Tinggi Ilmu Ekonomi (STIE) Labuhanbatu, Rantauprapat - Sumatera Utara

\begin{abstract}
Abstrak
Penelitian ini bertujuan untuk memberikan gambaran dan menganalisis pengaruh kualitas operasional sistem Siakad dan kualitas informasi Siakad terhadap kepuasan mahasiswa menggunakan Siakad dalam proses pembelajaran. Populasi penelitian ini adalah seluruh mahasiswa manajemen STIE Labuhanbatu semester VI TA. 2018/2019, dan sampelnya berjumlah 72 orang yang diturunkan dari rumus Slovin. Selajutnya, penetapan responden dilakukan dengan beberapa kriteria tertentu (purposive sampling) agar memenuhi maksud dan tujuan penelitian ini. Pengumpulan data dilakukan dengan wawancara terstruktur dan mendalam, selanjutnya temuan hasil penelitian disajikan secara deskriptif kualitatif.

Gambaran kepuasan mahasiswa terhadap Siakad ditinjau dari segi kualitas Sistem Siakad yaitu Easy of Use, Response Time, Reliability, dan Security dan segi kualitas Informasi Siakad yaitu Akurasi, Ketepatan Waktu, Relevansi, dan Kelengkapan. Pada kenyataannya, ditemukan beberapa kelemahan dan hambatan dalam operasionalisasi Siakad yang dapat diatasi dengan melakukan sejumlah perbaikan dan inovasi.
\end{abstract}

\section{Kata Kunci : siakad, kepuasan, pembelajaran}

\section{Pendahuluan}

Perkembangan teknologi saat ini telah mengalami peningkatan yang sangat pesat. Perkembangan teknologi saat ini telah merambah dan terjadi di semua segi kehidupan manusia. Salah satu teknologi yang mengalami perkembangan yang sangat pesat adalah perkembangan teknologi komputer yang telah mengalami evolusi yang sangat cepat. Dengan adanya perkembangan komputer dapat memberikan banyak keuntungan berupa ketepatan waktu, berkurangnya penanganan dokumen, dan beberapa manfaat lainnya, serta yang terutama telah menjadikan informasi menjadi sesuatu yang sangat penting.

Adanya perkembangan teknologi yang ada harus dimanfaatkan oleh semua organisasi agar organisasi mampu mencapai tujuan yang telah ditetapkan oleh organisasi. Oleh karena inilah organisasi membutuhkan suatu sistem. Sistem yang memanfaatkan teknologi, terutama komputer, dalam mengolah infomasi yang dapat membentuk suatu sistem informasi berbasis komputer yang andal untuk memperoleh hasil yang maksimal dalam memenuhi kebutuhan organisasinya.

STIE Labuhanbatu sebagai salah satu organisasi pendidikan yang senantiasa bergerak dinamis telah menggunakan sebuah sistem teknologi informasi dalam memenuhi kebutuhan informasi bagi stakeholder internalnya (mahasiswa, dosen dan tenaga kependidikan). Sistem online berbasis web dinamakan Siakad (Sistem Informasi Akademik) STIE Labuhanbatu. 
Siakad diperkenalkan kepada civitas akademika STIE Labuhanbatu Rantauprapat mulai tahun 2012, dan berfungsi sebagai acuan dalam tatalaksana akademik bagi mahasiswa, dosen, dan tenaga kependidikan lainnya dalam menjalankan fungsi dan tugasnya masing-masing.

Secara khusus bagi mahasiswa STIE Labuhanbatu tersedianya Siakad Online ini diharapkan dapat membantu mahasiswa dalam mengakses informasi akademik sehingga dapat merencanakan, mempertimbangkan dan menentukan keputusan akademiknya sendiri secara mandiri. Sejumlah konten kegiatan administrasi akademik telah tersedia dalam Siakad, misalnya pengisian Kartu Rencana Studi (KRS), pengunduhan Kartu Hasil Studi (KHS), informasi kelas dan dosen, pengunduhan bahan ajar, jadwal kuliah, jadwal ujian, serta informasi akademik lainnya.

Sebagaimana yang sering terjadi pada pengoperasian sistem online berbasis web lainnya, pada Siakad juga ditemukan berbagai hambatan yang dianggap menjadi penyebab kurang memuaskan operasional Siakad bagi mahasiswa sebagai user (pengguna) Siakad dalam menunjang proses pembelajaran. Beberapa hambatan tersebut misalnya kesulitan akses ke portal Siakad terutama saat awal tahun ajaran baru, sistem error pada saat proses berjalan, informasi kelas dan jadwal yang kurang up to date, tampilan bilah menu yang kurang menarik/ kurang komunikatif, dan sebagainya.

Kepuasan pengguna merupakan salah satu bentuk evaluasi terhadap sistem informasi. Salah satu metode yang dikembangkan oleh ahli sistem informasi untuk menggambarkan kepuasan pengguna sistem informasi adalah dengan menilai kualitas sistem (karakteristik sistem), kualitas informasi (output sistem), dan kualitas pelayanan (dukungan personil sistem). Dalam penelitian ini, gambaran kepuasan mahasiswa terhadap Siakad adalah pada kualitas sistem dan kualitas informasi yang diinginkan.

Berdasarkan uraian latar belakang tersebut, maka penulis tertarik untuk melakukan penelitian dengan judul “Analisis Kepuasan Mahasiswa Menggunakan

Siakad dalam Proses Pembelajaran (Studi pada Mahasiswa STIE Labuhanbatu)”.

Tujuan penelitian ini adalah memberikan gambaran kepuasan mahasiswa menggunakan Siakad ditinjau dari kualitas operasional sistem Siakad dan kualiatas informasi Siakad, sedangkan manfaat yang hendak dicapai adalah akan memberikan kontribusi kepada institusi STIE Labuhanbatu dalam hal penyempurnaan operasionalisasi sistem Siakad dan penyempurnaan kualitas informasi Siakad sehingga memberikan kepuasan bagi mahasiswa dalam menunjang proses pembelajaran.

\section{Uraian Teoritis}

\subsection{Sistem Informasi}

Sistem informasi adalah seperangkat komponen yang saling berhubungan yang fungsi untuk utama mengumpulkan, memproses, menyimpan dan mendistribusikan informasi untuk mendukung pembuatan keputusan dan pengawasan dalam organisasi (Husein dan Amin Wibowo, 2002: 8). Menurut AlBahra bin Ladjamudin (2005:13) sistem informasi dapat didefinisikan sebagai suatu sistem yang dibuat manusia yang terdiri dari komponenkomponen dalam organisasi untuk mencapi suatu tujaun yaitu menyajikan informasi.

Pengunaan sistem informasi dalam organisasi telah meningkat secara dramatis. Sejak tahun 1980-an, sekitar 50 persen modal baru digunakan untuk pengembangan sistem informasi (Venkatesh et.al., 2003). Sistem informasi diadakan untuk menunjang aktifitas usaha di semua tingkatan organisasi. Penggunaan sistem informasi mencakup sampai ke 
tingkat operasional untuk meningkatkan kualitas produk serta produktivitas operasi. Sistem informasi akan memberikan kemudahan bagi para manajerial untuk menghasilkan informasi yang dapat dipercaya, relevan, tepat waktu, dapat dipahami dan teruji sehingga akan membantu pengambilan keputusan.

\subsection{Kualitas Operasional Sistem}

Kualitas operasional sistem menurut DeLone dan McLean (2003) adalah kualitas dari kombinasi hardware dan software dalam sistem informasi. Fokusnya adalah performa dari sistem, yang merujuk pada seberapa baik kemampuan perangkat keras, perangkat lunak, kebijakan, prosedur dari sistem informasi dapat menyediakan informasi kebutuhan pengguna. Menurut Swanson (1974) dalam buku Jogiyanto (2007:12) menyatakan untuk mengukur kualitas operasional sistem maka, pengukuran yang digunakan adalah keandalan dari sistem komputer, waktu respon online dan kemudahan menggunakan terminal.

Selanjutnya, DeLone dan Mc.Lean menuliskan sejumlah indikator kualitas operasional sistem yang diharus dipenuhi oleh sebuah sistem, yaitu sebagai berikut :

\section{Ease of Use (Kemudahan Penggunaan Sistem)}

Suatu sistem informasi dapat dikatakan berkualitas jika sistem tersebut dirancang untuk memenuhi kepuasan pengguna melalui kemudahan dalam menggunakan sistem informasi tersebut yang pada akhirnya mempunyai pengaruh pada pemakai individu didalam melakukan pekerjaannya.

\section{Response Time (Kecepatan Akses Sistem)}

Kecepatan akses merupakan salah satu indikator kualitas sistem informasi. Jika akses sistem informasi yang memiliki kecepatan yang optimal maka layak dikatakan bahwa sistem informasi yang diterapkan mempunyai kualitas yang baik. Kecepatan akses akan meningkatkan kepuasan pengguna dalam menggunakan sistem informasi untuk memudahkan proses kerja individu yang akan berdampak pada peningkatan kinerja perusahaan.

\section{Reliability (Keandalan Sistem)}

Sistem informasi yang berkualitas adalah sistem informasi yang dapat diandalkan. Jika sistem tersebut dapat diandalkan maka sistem informasi tersebut layak digunakan. Keandalan sistem informasi ini adalah ketahanan sistem informasi dari kerusakan dan kesalahan. Keandalan sistem informasi dapat dilihat dari sistem infmasi yang melayani kebutuhan pengguna tanpa adanya masalah yang dapat mengganggu kenyamanan oengguna dalam menggunakan sistem informasi.

\section{Security (Keamanan Sistem)}

Suatu sistem informasi dikatakan baik jika keamanan sistem tersebut dapat diandalkan. Keamanan sistem ini dapat dilihat melalui data pengguna yang aman disimpan oleh suatu sistem informasi. Data pengguna ini harus terjaga kerahasiaannya dengan cara data tersimpan oleh sistem informasi sehingga pihak lain tidak dapat mengakses data tersebut secara bebas. Jika data pengguna dapat disimpan oleh sistem informasi secara aman maka, akan memperkecil kesempatan pihak lain untuk menyalahgunakan data pengguna sistem informasi. 


\subsection{Kualitas Informasi}

Informasi memiliki peranan penting dalam keberlangsungan suatu organisasi. Dapat dikatakan organisasi yang dapat mengelola informasi secara efektif dan efisien satu langkah di depan dari para pesaingnya. Adapun pengertian informasi menurut Mc.Fadden dkk (1999) dalam Abdul Kadir (2002:31) mendefinisikan informasi sebagai data yang telah diproses sedemikian rupa sehingga meningkatkan pengetahuan seseorang yang menggunakan data tersebut.

Dari pengertian diatas dipahami bahwa informasi merupakan kumpulan data yang dapat dimengerti dan digunakan oleh pengguna dan memiliki arti. Sedangkan secara umum definisi para ahli mengenai informasi dapat diartikan sebagai hasil dari pengolahan data dalam suatu bentuk yang lebih berguna dan lebih berarti bagi penerimanya yang menggambarkan suatu kejadian-kejadian yang nyata yang digunakan untuk pengambilan keputusan.

Syarat agar informasi yang dihasilkan oleh sistem informasi lebih berkualitas maka sebuah informasi harus memenuhi sejumlah indikator. Menurut Abdul Kadir (2002:35), indikator kualitas informasi yang dimaksud tersebut adalah sebagai berikut :

1. Akuransi Informasi (Accuracy) berarti informasi harus bebas dari kesalahankesalahan dan tidak menyesatkan. Akurat juga berarti informasi harus jelas mencerminkan maksudnya. Informasi harus akurat karena dari sumber informasi sampai ke penerima informasi kemungkinan banyak terjadi gangguan (noise) yang dapat merubah atau merusak informasi tersebut.

2.

3. Ketepatan waktu Informasi (TimeLinnes) berarti informasi yang datang pada penerima tidak boleh terlambat. Informasi yang sudah usang tidak akan mempunyai nilai lagi. Karena informasi merupakan landasan di dalam pengambilan keputusan. Bila pengambilan keputusan terlambat, maka dapat berakibat fatal untuk organisasi.

4.

5. Relevansi Informasi (Relevancy) berarti informasi tersebut mempunyai manfaat untuk pemakainya, relevansi informasi untuk tiap-tiap orang satu dengan yang lainnya berbeda.

6.

7. Kelengkapan Informasi (Complete) berarti informasi harus diberikan secara lengkap, sistematis, dan ada buktinya.

\section{Metodologi}

Metode yang digunakan dalam penelitian ini adalah metode penelitian deskriptif kualitatif. Penelitian deskriptif kualitatif adalah penelitian yang menggambarkan atau melukiskan objek penelitian berdasarkan fakta-fakta yang tampak atau sebagaimana adanya. Menurut Sugiono (2012:15), metode penelitian deskriptif kualitatif merupakan metode penelitian yang berlandaskan pada filsafat positivisme, digunakan untuk meneliti pada kondisi obyek yang alamiah (apa adanya) dengan analisis data bersifat kualitatif, dimana penelitian lebih menekan makna dari pada generalisasi. 
Populasi penelitian ini adalah seluruh mahasiswa manajemen STIE Labuhanbatu semester VI TA. 2018/2019, dan sampelnya berjumlah 72 orang yang diturunkan dari rumus Slovin. Selajutnya, penetapan responden dilakukan dengan beberapa kriteria tertentu (purposive sampling) agar memenuhi maksud dan tujuan penelitian ini (Arikuto : 2006). Pengumpulan data dilakukan dengan wawancara terstruktur dan mendalam, selanjutnya temuan penelitian disajikan secara deskriptif kualitatif dalam uraian kata-kata.

\section{Hasil dan Pembahasan}

\subsection{Pengaruh Penerapan Siakad terhadap aktivitas Mahasiswa STIE Labuhanbatu} Sebelum penerapan Siakad, semua aktivitas akademik mahasiswa/i STIE Labuhanbatu dilakukan secara manual. Sebagaimana diketahui, setiap akan memulai tahun ajaran baru, seluruh mahasiswa/i wajib memperoleh KHS (Kartu Hasil Studi) dari Biro STIE, mengisi KRS (Kartu Rencana Studi), selanjutnya menemui Dosen Penasehat Akademik untuk menandatangai KRS, dan selanjutnya memasukkan semua berkas tersebut dalam map dan mengembalikannya ke Biro STIE Labuhanbatu. Seluruh aktivitas tersebut dirasakan cukup menyita waktu, tenaga dan biaya. Keadaan ini semakin diperberat oleh keterbatasan jam operasional Biro STIE (Senin-Sabtu pada jam kerja) dan ketersediaan waktu Dosen Penasehat Akademik sehingga tak jarang mahasiwa harus bolak/i ke kampus.

Berikut ini perbedaan aktivitas mahasiwa sebelum dan sesudah penerapan Siakad : 
Tabel 4.1. Perbedaan Aktivitas Mahasiswa Sebelum dan Sesudah Penerapan Siakad

\begin{tabular}{|c|c|c|}
\hline Aktivitas & Sebelum & Sesudah \\
\hline 1. Pengambilan KHS & $\begin{array}{l}\text { Mahasiswa harus datang ke } \\
\text { kampus }\end{array}$ & $\begin{array}{l}\text { Karena sudah Online, } \\
\text { mahasiswa dapat mengunduh } \\
\text { KHS dari portal } \\
\text { siakad.stielabuhanbatu.ac.id, } \\
\text { dari mana saja, kapan saja }\end{array}$ \\
\hline 2. Pengisian KRS & $\begin{array}{l}\text { Mahasiswa harus } \\
\text { mengambil formulir dari } \\
\text { kampus }\end{array}$ & $\begin{array}{l}\text { Mahasiswa mengisi KRS } \\
\text { secara Online }\end{array}$ \\
\hline 3. Validasi Penasehat & Mahasiswa harus bertemu & Mahasiswa tidak perlu \\
\hline Akademik & dosen penasehat akademik & $\begin{array}{l}\text { bertemu dosen penasehat } \\
\text { akademik }\end{array}$ \\
\hline $\begin{array}{l}\text { 4. Pengembalian } \\
\text { Berkas }\end{array}$ & $\begin{array}{l}\text { Mahasiswa harus ke } \\
\text { kampus menyerahkan } \\
\text { berkas dalam map }\end{array}$ & $\begin{array}{l}\text { Semua data sudah tersimpan } \\
\text { dalam server Siakad, sehingga } \\
\text { mahasiswa tidak perlu } \\
\text { menyerahkan berkas fisik }\end{array}$ \\
\hline 5. Jadwal Kuliah & $\begin{array}{l}\text { Mahasiswa harus ke } \\
\text { kampus untuk melihat } \\
\text { jadwal kuliah }\end{array}$ & $\begin{array}{l}\text { Jadwal kuliah dapat dilihat } \\
\text { pada Siakad }\end{array}$ \\
\hline 6. Nilai & $\begin{array}{l}\text { Mahasiswa harus ke } \\
\text { kampus untuk melihat nilai }\end{array}$ & Nilai dapat dilihat di Siakad \\
\hline 7. Bahan Ajar & $\begin{array}{l}\text { Mahasiswa menunggu } \\
\text { dosen memberikan bahan } \\
\text { ajar dalam bentuk file atau } \\
\text { fotocopy }\end{array}$ & $\begin{array}{l}\text { Bahan ajar dapat diunduh dari } \\
\text { Siakad }\end{array}$ \\
\hline
\end{tabular}

Secara umum, penerapan Siakad banyak membantu mahasiwa dalam merencanakan, mempertimbangkan, dan mengambi keputusan akademik secara mandiri. Siakad Online terbukti telah memberikan efisiensi bagi mahasiswa/i baik dari segi waktu, tenaga dan biaya.

\subsection{Kepuasan Mahasiswa terhadap Kualitas Operasional Sistem Siakad}

Penerapan Siakad telah banyak memberikan efisiensi bagi mahasiswa, namun sama seperti pengoperasian sistem online berbasis web lainnya, pada Siakad juga ditemukan berbagai hambatan/masalah yang menjadi penyebab kurang memuaskannya Siakad bagi mahasiswa sebagai user (pengguna) Siakad. Berikut ini ditampilkan gambaran kepuasan mahasiswa terhadap Operasional Sistem Siakad. 
Tabel 4.2. Kepuasan Mahasiswa Terhadap Kualitas Operasional Sistem Siakad

\begin{tabular}{|c|c|c|c|c|c|}
\hline \multirow[t]{2}{*}{ Aktivitas } & \multicolumn{4}{|c|}{$\begin{array}{c}\text { Tanggapan terhadap Kualitas Operasional } \\
\text { Sistem }\end{array}$} & \multirow[t]{2}{*}{ Keterangan } \\
\hline & $\begin{array}{c}\begin{array}{c}\text { Ease of } \\
\text { Use } \\
\text { (kemudahan } \\
\text { penggunaan) }\end{array} \\
\end{array}$ & $\begin{array}{l}\text { Respose } \\
\text { Time } \\
\text { (kecepatan } \\
\text { akses) }\end{array}$ & $\begin{array}{r}\text { Reliability } \\
\text { (tahan dari } \\
\text { kerusakan) }\end{array}$ & $\begin{array}{l}\text { Security } \\
\text { (rahasia data } \\
\text { terjamin) }\end{array}$ & \\
\hline 1. Login User & mudah & $\begin{array}{l}\text { cukup } \\
\text { lambat }\end{array}$ & stabil & terjamin & $\begin{array}{l}\text { Secara umum } \\
\text { mahasiswa cukup } \\
\text { puas saat login user }\end{array}$ \\
\hline $\begin{array}{l}\text { 2.Pengunduhan } \\
\text { KHS }\end{array}$ & sulit & lambat & $\begin{array}{l}\text { sering } \\
\text { down }\end{array}$ & $\begin{array}{l}\text { cukup } \\
\text { terjamin }\end{array}$ & $\begin{array}{l}\text { Secara umum } \\
\text { mahasiswa kurang } \\
\text { puas saat mengunduh } \\
\text { KHS }\end{array}$ \\
\hline $\begin{array}{l}\text { 3. Pengisian } \\
\text { KRS }\end{array}$ & mudah & $\begin{array}{l}\text { cukup } \\
\text { lambat }\end{array}$ & $\begin{array}{l}\text { sering } \\
\text { down }\end{array}$ & terjamin & $\begin{array}{l}\text { Secara umum } \\
\text { mahasiswa kurang } \\
\text { puas saat mengisi } \\
\text { KRS }\end{array}$ \\
\hline $\begin{array}{l}\text { 4. Melihat Kelas } \\
\text { dan Jadwal } \\
\text { Kuliah }\end{array}$ & sulit & $\begin{array}{l}\text { cukup } \\
\text { lambat }\end{array}$ & $\begin{array}{l}\text { cukup } \\
\text { stabil }\end{array}$ & terjamin & $\begin{array}{l}\text { Secara umum } \\
\text { mahasiswa kurang } \\
\text { puas saat mengakses } \\
\text { menu melihat kelas } \\
\text { dan jadwal kuliah }\end{array}$ \\
\hline $\begin{array}{l}\text { 5. Pengunduhan } \\
\text { Bahan Ajar }\end{array}$ & sulit & lambat & $\begin{array}{l}\text { sering } \\
\text { down }\end{array}$ & terjamin & $\begin{array}{l}\text { Secara umum } \\
\text { mahasiswa tidak puas } \\
\text { saat mengunduh } \\
\text { bahan ajar }\end{array}$ \\
\hline 6. Melihat Nilai & cukup sulit & lambat & $\begin{array}{l}\text { sering } \\
\text { down }\end{array}$ & $\begin{array}{l}\text { cukup } \\
\text { terjamin }\end{array}$ & $\begin{array}{l}\text { Secara umum } \\
\text { mahasiswa tidak } \\
\text { puas saat mengakses } \\
\text { menu melihat nilai }\end{array}$ \\
\hline $\begin{array}{l}\text { 7. Melihat } \\
\text { Kemajuan } \\
\text { Akademik } \\
\text { (IPK) }\end{array}$ & cukup sulit & lambat & $\begin{array}{l}\text { sering } \\
\text { down }\end{array}$ & $\begin{array}{l}\text { cukup } \\
\text { terjamin }\end{array}$ & $\begin{array}{l}\text { Secara umum } \\
\text { mahasiswa tidak } \\
\text { puas saat mengakses } \\
\text { menu melihat }\end{array}$ \\
\hline
\end{tabular}

Secara umum, mahasiswa merasa kurang puas terhadap Kualitas Operasional Sistem yang ada pada Siakad. Kekurangpuasan ini pada umumnya terjadi pada saat melakukan aktivitas Mengunduh KHS, Mengisi KRS, dan Melihat Kelas dan Jadwal Kuliah. Bahkan mahasiswa merasa tidak puas terhadap operasional sistem Siakad pada saat melakukan aktivitas Mengunduh Bahan Ajar, Melihat Nilai, dan Melihat Kemajuan Akademik (IPK). Hambatan/masalah yang paling sering ditemukan ketika mengoperasikan Siakad adalah notifikasi sistem error dan time out. 


\subsection{Kepuasan Mahasiswa terhadap Kualitas Informasi Siakad}

Berikut ini ditampilkan gambaran kepuasan mahasiswa terhadap Kualitas Informasi Siakad.

Tabel 4.3. Kepuasan Mahasiswa Terhadap Kualitas Informasi Siakad

\begin{tabular}{|c|c|c|c|c|c|}
\hline \multirow{2}{*}{$\begin{array}{c}\text { Tampilan } \\
\text { Informasi } \\
\text { Siakad }\end{array}$} & \multicolumn{4}{|c|}{ Tanggapan terhadap Kualitas Informasi Siakad } & \multirow[t]{2}{*}{ Keterangan } \\
\hline & $\begin{array}{l}\text { Akuransi } \\
\text { (kejelasan) }\end{array}$ & $\begin{array}{l}\text { Ketepatan } \\
\text { Waktu }\end{array}$ & $\begin{array}{c}\text { Relevansi } \\
\text { (kebermanfa } \\
\text { atan) }\end{array}$ & $\begin{array}{l}\text { Kelengkap } \\
\text { an }\end{array}$ & \\
\hline $\begin{array}{l}\text { 1.Informasi } \\
\text { Login } \\
\text { User }\end{array}$ & jelas & cepat & bermanfaat & lengkap & $\begin{array}{lr}\text { Secara } & \text { umum } \\
\text { mahasiswa } & \text { puas } \\
\text { terhadap } & \text { kualitas } \\
\text { infomasi untuk login } \\
\text { user }\end{array}$ \\
\hline $\begin{array}{l}\text { 2.Informasi } \\
\text { KHS }\end{array}$ & jelas & cukup cepat & bermanfaat & $\begin{array}{l}\text { cukup } \\
\text { lengkap }\end{array}$ & $\begin{array}{l}\text { Secara umum } \\
\text { mahasiswa cukup puas } \\
\text { terhadap kualitas } \\
\text { informasi yang tertera } \\
\text { dalam KHS }\end{array}$ \\
\hline \multirow[t]{2}{*}{$\begin{array}{l}\text { 3.Informasi } \\
\text { KRS }\end{array}$} & jelas & cepat & bermanfaat & lengkap & $\begin{array}{l}\text { Secara } \\
\text { mahasiswa puas }\end{array}$ \\
\hline & & & & & $\begin{array}{l}\text { terhadap kualitas } \\
\text { informasi yg tertera } \\
\text { pada KRS } \\
\end{array}$ \\
\hline $\begin{array}{l}\text { 4.Informasi } \\
\text { Kelas dan } \\
\text { Jadwal } \\
\text { Kuliah }\end{array}$ & $\begin{array}{l}\text { kurang } \\
\text { elas }\end{array}$ & cukup cepat & $\begin{array}{l}\text { cukup } \\
\text { bermanfaat }\end{array}$ & $\begin{array}{l}\text { tidak } \\
\text { lengkap }\end{array}$ & $\begin{array}{l}\text { Secara umum } \\
\text { mahasiswa tidak puas } \\
\text { terhadap kualitas } \\
\text { informasi kelas dan } \\
\text { jadwal kuliah }\end{array}$ \\
\hline $\begin{array}{l}\text { 5.Informa } \\
\text { si Bahan } \\
\text { Ajar }\end{array}$ & $\begin{array}{l}\text { kurang } \\
\text { jelas }\end{array}$ & lambat & $\begin{array}{l}\text { cukup } \\
\text { bermanfaat }\end{array}$ & $\begin{array}{l}\text { tidak } \\
\text { lengkap }\end{array}$ & $\begin{array}{lr}\text { Secara } & \text { umum } \\
\text { mahasiswa } & \text { tidak puas } \\
\text { terhadap kualitas } \\
\text { informasi bahan ajar }\end{array}$ \\
\hline $\begin{array}{l}\text { 6.Informasi } \\
\text { Nilai }\end{array}$ & jelas & cukup cepat & bermanfaat & $\begin{array}{l}\text { cukup } \\
\text { lengkap }\end{array}$ & $\begin{array}{l}\text { Secara umum } \\
\text { mahasiswa cukup puas } \\
\text { terhadap kualitas } \\
\text { informasi nilai }\end{array}$ \\
\hline $\begin{array}{l}7 . \\
\text { Informasi } \\
\text { kemajuan } \\
\text { akademik } \\
(\text { IPK) }\end{array}$ & $\begin{array}{l}\text { kurang } \\
\text { jelas }\end{array}$ & cepat & bermanfaat & $\begin{array}{l}\text { kurang } \\
\text { lengkap }\end{array}$ & $\begin{array}{lr}\text { Secara } & \text { umum } \\
\text { mahasiswa } & \text { kurang } \\
\text { puas tehadap kualitas } \\
\text { informasi kemajuan } \\
\text { akademik (IPK) }\end{array}$ \\
\hline
\end{tabular}


Secara umum, mahasiswa merasa cukup puas dengan kualitas informasi yang ada pada Siakad. Mahasiswa hanya merasa puas pada akurasi, ketepatan waktu, dan kelengkapan informasi yang tersaji dalam informasi KRS, cukup puas pada kualitas informasi KHS dan Informasi Nilai, dan kurang puas pada informasi kemajuan akademik (IPK). Beberapa mahasiswa bahkan menyatakan tidak puas pada kualitas informasi yang terdapat pada bagian Informasi Kelas, Jadwal Kuliah dan Bahan Ajar. Ketidakpuasan ini timbul karena pada Siakad masih ditemukan masalah seperti keterlambatan input nilai akhir, beberapa nilai akhir yang berubah sehingga mengakibatkan penurunan IPK, informasi kelas dan jadwal kuliah masih sering berubah bahkan saat perkuliahan perdana telah dimulai, dan masih ada ditemukan beberapa mata kuliah tidak mempunyai bahan ajar.

\section{Kesimpulan dan Saran}

Sebagai kesimpulan, bahwa penerapan Siakad dalam proses pembelajaran telah banyak membantu mahasiswa/i STIE Labuhanbatu dalam merencanakan, mempertimbangkan, dan mengambi keputusan akademik secara mandiri. Siakad terbukti telah memberikan efisiensi bagi mahasiswa/i baik dari segi waktu, tenaga dan biaya. Hanya saja berjalannya Siakad ini belum ditunjang dengan sebuah jaringan yang mampu memberikan daya tampung terhadap imlementasi penggunaan portal ini baik dari segi kualitas Operasional Sistem Siakad maupun kualitas Informasi Siakad. Pada kenyataannya, masih ditemukan beberapa hambatan dan masalah dalam operasionalisasinya yang dapat merugikan mahasiswa sebagai user (pengguna) Siakad.

Saran yang bisa diberikan adalah agar pihak manajemen STIE Labuhanbatu lebih memperhatikan dan menuntaskan masalah yang terjadi dari waktu ke waktu yaitu masalah teknis jaringan dan koneksi internet yang menjadi backbone (tulang punggung) lancar dan nyamannya penerapan Siakad di kampus, terutama di masa-masa memasuki tahun ajaran baru dimana aktivitas penggunaan Siakad oleh semua user akan meningkat tajam. Disamping itu agar lebih memperhatikan dan memperbaiki kelemahan-kelemahan dari segi kualitas Operasional Sistem Siakad (Easy of Use, Response Time, Reliability, dan Security) dan kualitas Informasi Siakad (Akurasi, Ketepatan Waktu, Relevansi, dan Kelengkapan) dengan melakukan perbaikan sistem dan inovasi.

\section{Daftar Pustaka}

Arikunto, Suharsimi. 2006. Prosedur Penelitian: Suatu Pendekatan Praktek. Jakarta: Rineka Cipta

Agustiani, Nurul Huda. 2010. Pengaruh Pemanfaatan Sistem Informasi Akademik Terpadu (Sikadu) Terhadap Kinerja Individual Dengan Kemudahan Penggunaan Sebagai Variabel Moderating (Studi Empiris pada Fakultas Teknik Universitas Negeri Semarang). Tesis

Azhar Susanto. 2008. Sistem Informasi Akuntansi-Struktur-Pengendalian-Resiko 
Pengembangan. Cetakan Pertama. Bandung : Penerbit Lingga Jaya

Bungin, Burhan. 2009. Metode Penelitian Kualitatif. Jakarta: Penerbit Kencana

DeLone, W.H and McLean, E.R. 2003. The DeLone and McLean Model of Sistem Success: A Ten-Year Update, Journal of Mangement Information Sistem, 19 (4), 9-30.

Hairul, Anwar. 2017. Analisis Kepuasan Pelayanan Portal Akademik di

Universitas Maritim Raja Ali Haji, Tanjung Pinang : Naskah Publikasi

Husein, Muhammad Fakhri dan Wibowo, Amin. 2002. Sistem Informasi Manajemen. UPP AMP YKPN. Yogyakarta

Jogiyanto, HM. 2007. Model Kesuksesan Sistem Teknologi Informasi. Yogyakarta: Penerbit Andi

Kadir, Abdul. 2002. Pengenalan Sistem Informasi. Yogyakarta : Penerbit Andi

Ladjamudin, Al-Bahra. 2005. Analisis dan Desain Sistem Informasi. Yogyakarta: Graha Ilmu

Salamah, Irma. 2015. Faktor-faktor Yang Mempengaruhi Minat Pemanfaatan Sistem Informasi dan Penggunaan Sistem Informasi (Studi Empiris

Pada Staff Administrasi Politeknik Negeri Sriwijaya). Seminar Nasional Ilmu Komputer (SNIK 2015). Semarang

Sugiono. 2012. Metode Penelitian Kuantitatif, Kualitatif, dan R\&D. Bandung: Penerbit Alfabeta

Venkatesh, V., Morris, M. G., Davis, G. B., dan Davis, F. D. 2003. User Acceptance of Information Technology. MIS Quarterly. Vol.27, No. 3.

hal. $425-478$ 